\title{
PKM Desain dan Konsultasi Rumah Sehat di Desa Mekarwangi, Banten
}

Muhammar Khamdevi ${ }^{1}$, Andrey Caesar Effendi ${ }^{2}$, Danang Harito Wibowo ${ }^{3}$

e-mail:m.khamdevi@gmail.com ${ }^{1}$

Program Studi Arsitektur, Universitas Matana ${ }^{1,2,3}$

\section{Abstrak}

Rumah-rumah di Kampung Cilegong, Desa Mekarwangi masih jauh dari standard Rumah Sehat. Meskipun beberapa dibangun sendiri oleh tukang dengan ilmu "copy-paste" dari perumahan cluster, ternyata ada juga yang beberapa dibangun oleh pemerintah daerah dan dinas. Rumah yang sehat adalah rumah yang didesain dengan baik, terutama melihat konteks iklim setempat. Pencahayaan dan penghawaan alami menjadi syarat utama dalam merancang rumah sehat. Oleh karena itu, Prodi Arsitektur Universitas Matana mencoba melaksanakan kegiatan PKM dalam bentuk pelatihan, konsultasi, dan pendampingan beberapa rumah di Kampung Cilegong. Diharapkan warga Kampung Cilegong dan masyarakat Desa Mekarwangi terpapar pengetahuan mengenai Rumah Sehat dan mendapatkan solusi desain untuk menjadi contoh. Kegiatan ini melibatkan mahasiswa angkatan 2018 Universitas Matana dan diintegrasikan dengan mata kuliah Fisika Bangunan dan Studio Perancangan Ruang Dalam. Metode pelaksanaan dilaksanakan mengikuti metode perancangan. Hasil kegiatan menunjukkan respon positif dan penambahan wawasan oleh masyarakat.

Kata Kunci: rumah sehat, pengabdian kepada masyarakat, desa mekarwangi, perancangan arsitektur

\section{Abstract}

The houses in Kampung Cilegong, Mekarwangi Village are still far from the standard of Healthy Homes. Although some were built by artisans with the knowledge of "copy-paste" from cluster housing, there were also some that were built by local governments and offices. A healthy home is a well-designed house, especially looking at the local climate context. Natural lighting and air are the main requirements in designing a healthy home. Therefore, the Architecture Study Program at Matana University tries to carry out PKM activities in the form of training, consultation, and mentoring of several houses in Kampung Cilegong. It is hoped that residents of Kampung Cilegong and the people of Mekarwangi Village will be exposed to the knowledge of the Healthy House and obtain design solutions to set an example. This activity involved students of the 2018 class at Matana University and was integrated with the Building Physics course and the Interior Design Studio. The method of implementation is carried out following the design method. The results of the activity showed a positive response and added insight by the community.

Keywords: healthy house, community service, mekarwangi village, architectural design 


\section{Pendahuluan}

Desa Mekarwangi merupakan salah satu desa terpencil dan tertinggal di Kecamatan Cisauk, Kabupaten Tangerang, seluas sekitar 434 ha, lihat Gambar 1. Beberapa lahan telah terbeli oleh para pengembang properti. Pendidikan penduduknya mayoritas tidak tamat SD (Desa Mekarwangi, 2013 dan Desa Mekarwangi, 2015). Desa ini dikhawatirkan akan menjadi urban void yang berpotensi menjadi kampung kumuh (Khamdevi dan Wibowo, 2016). Padahal desa ini memiliki potensi lokal sebagai dewa agrowisata (Khamdevi and Wibowo, 2018 dam Khamdevi, 2018).

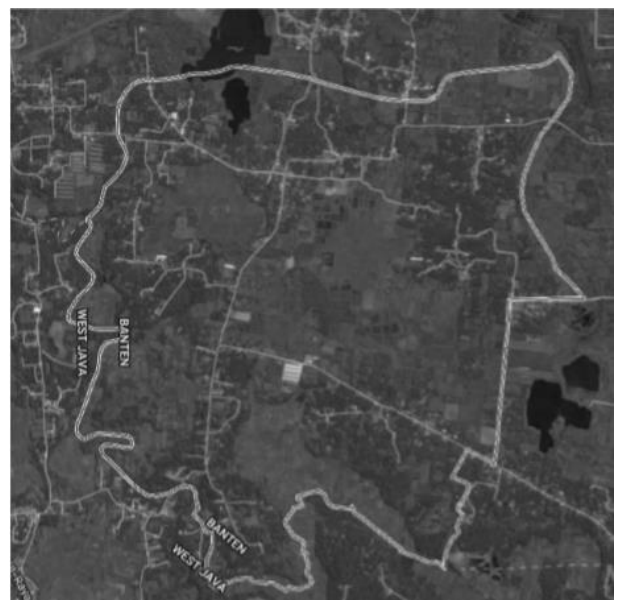

Gambar 1. Lokasi PKM (Sumber: Googlemaps, 2019)

Kampung Cilegong adalah salah satu wilayah Desa Mekarwangi, yang ditetapkan sebagai Rukun Warga (RW) 01. Kampung Cilegong dulu masih memiliki rumah-rumah tradisional yang khas. Namun rumah tradisional yang terakhir hilang pada tahun 2017 (Wibowo dan Khamdevi, 2017). Rumah-rumah yang ada sekarang seperti rumah-rumah modern minimalis dan ada pula beberapa bergaya klasik eropa. Rumah-rumah baru ini beberapa dibangun sendiri, beberapa dibangun oleh pihak dinas PU, Perumahan Rakyat, dan Kabupaten. Namun desain ini justru memiliki masalah pencahayaan dan penghawaan alami. Material yang digunakan sangat mudah menghatarkan panas (kalor) dari luar ke dalam rumah. Oleh karena ini kegiatan ini dilakukan untuk memberikan kosultasi dan pendampingan tentang Rumah Sehat.

\section{Metode Pelaksanaan}

Sasaran peserta kegiatan PKM ini adalah warga Kampung Cilegong secara khusus dan warga Desa Mekarwangi secara umum. Rumah yang menjadi kasus desain adalah 5 (lima) rumah. Kegiatan dilaksanakan di Kampung Cilegong dan secara berkala yang berjumlah 50 (limapuluh) jam, yang waktunya akan ditentukan ketika dilakukan analisis dan evaluasi awal. Tahapan pelaksanaan sebagai berikut:

1. Pendampingan Survey Lapangan

2. Pembimbingan Analisis Data Lapangan, Konsep, dan Desain

3. Pendampingan Presentasi Hasil dan Konsultasi Rumah Sehat

4. Pembuatan Dokumen untuk Kelurahan, LPPM, Perpustakaan, dan Prodi

Kegiatan PKM yang dijadikan solusi adalah sebagai berikut: 
1. Konsultasi dan Desain Rumah Sehat dalam aspek Fisika Bangunan (pencahayaan dan penghawaan alami)

2. Konsultasi dan Desain Rumah Sehat dalam aspek Arsitektur Interior

3. Konsultasi Pengetahuan Rumah Sehat

\section{Hasil dan Pembahasan}

Kegiatan ini menghasilkan manfaat pengetahuan dan wawasan warga akan rumah sehat. Rumah tidak saja hanya "molek" dilihat namun bias dihuni dengan layak dan sehat bagi penghuninya jika didesain dengan baik dan benar. Untuk kegiatan Survey Lapangan, Presentasi Hasil dan Konsultasi Rumah Sehat dilaksanakan di Kampung Cilegong. Sedangkan kegiatan Pembimbingan dilaksanakan 6 pertemuan di kelas oleh 1 Dosen Ketua pada Mata Kuliah Fisika Bangunan Program Studi Arsitektur, Universitas Matana. Pembimbingan di luar kelas juga dilakukan oleh 2 (dua) Dosen Anggota.

\section{Pendampingan Survey Lapangan}

Ada setidaknya 5 (lima) rumah yang akan desain:

a. Rumah Warung 2 (dua) buah untuk direnovasi

b. Rumah 1 (satu) buah untuk direnovasi

c. Rumah 2 (dua) buah untuk didesain baru
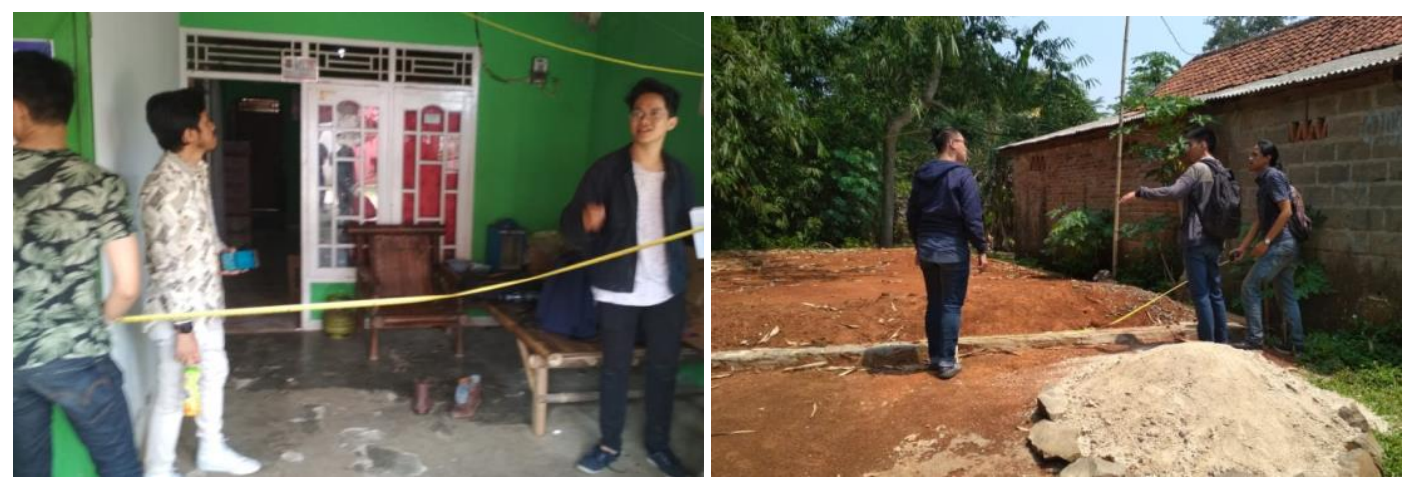

Gambar 2. Survey Lapangan (Sumber: Dokumentasi Pribadi, 2019)

\section{Pembimbingan Desain}

Pembimbingan desain dilaksanakan pada saat kuliah Fisika Bangunan sebanyak 6 (enam) kali pertemuan tiap mahasiswa. Pembimbing berjumlah sebanyak 3 (tiga) orang, di mananya salah satunya adalah Pembimbing Utama.

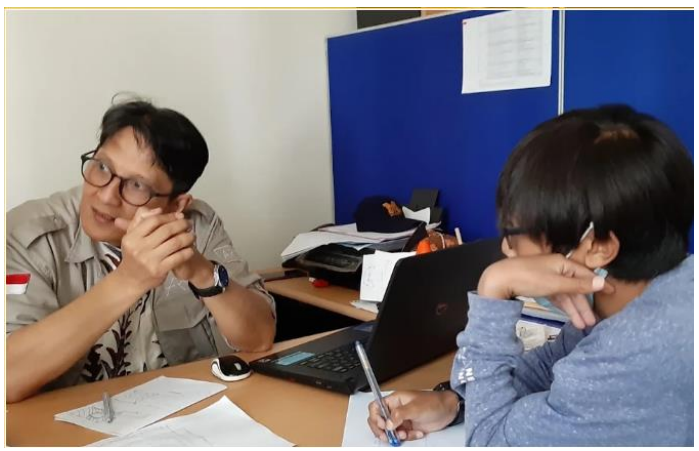

Gambar 3. Bimbingan Perancangan (Sumber: Dokumentasi Pribadi, 2019) 


\section{Pendampingan Presentasi}

Setelah desain selesai, maka tiap mahasiswa harus melakukan presentasi di depan warga dan pemerintah desa di kantor desa. Respon dari warga cukup antusias dan baik. Diharapkan pengetahuan dan wawasan masyarakat semakin teredukasi.
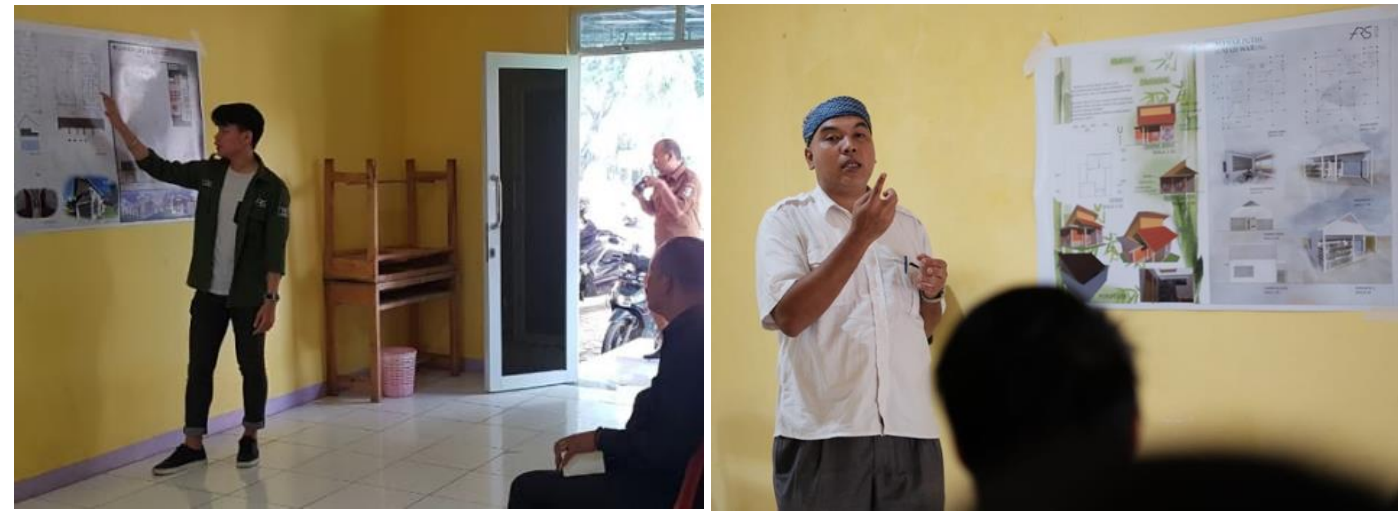

Gambar 4. Presentasi Hasil Desain (Sumber: Dokumentasi Pribadi, 2019)

\section{Pembuatan Dokumen}

Selain dokumen desain berupa gambar kerja, kegiatan ini juga menghasilkan Modul Materi Rumah Sehat dan Vlog pada Youtube sebagai berikut: https://www.youtube.com/watch?v=vcKg6ZVEm7Q.
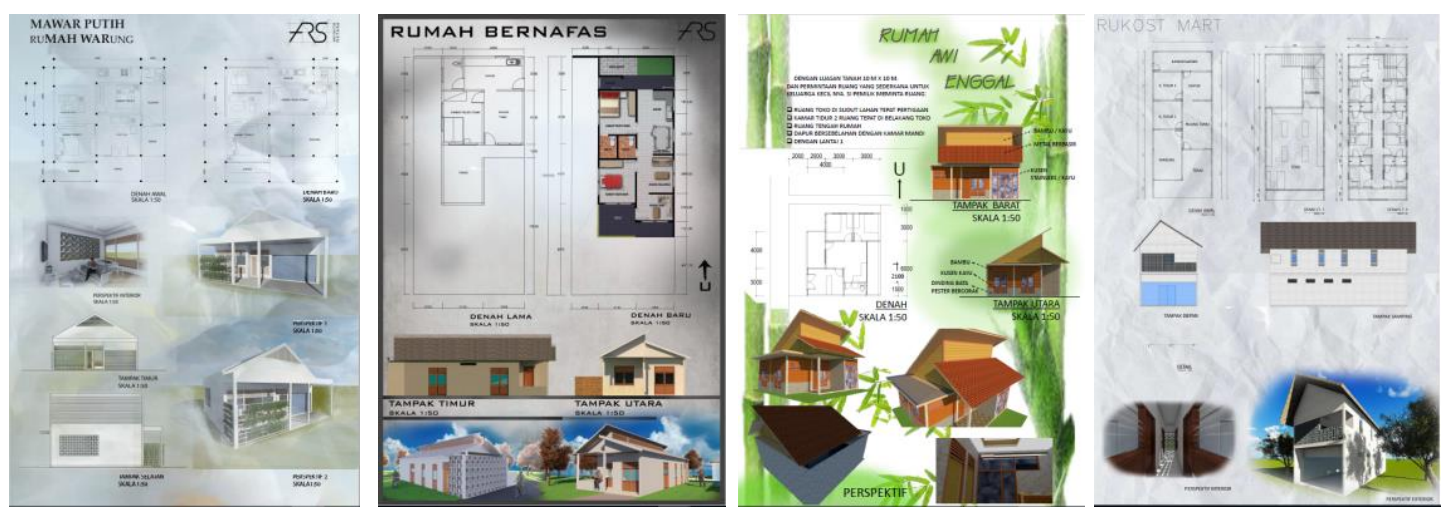

Gambar 5. Bimbingan Perancangan (Sumber: Dokumentasi Pribadi, 2019)

Dokumen Modul Materi Rumah Sehat diserahkan kepada pihak Pemerintah Desa dan Universitas Matana. Isi modul terdapat materi mengenai:
a. Pemanfaatan Lahan
b. Pemgelolaan Ruang
c. Pencahayaan Alami
d. Penghawaan Alami
e. Bahan dan Warna Bangunan 


\section{Kesimpulan}

Secara keseluruhan kegiatan ini sudah dipersiapkan dan dilaksanakan dengan baik dan maksimal. Semoga kegiatan ini merubah mindset warga untuk memiliki rumah yang tidak saja "molek" namun layak dan sehat. Untuk ke depannya, PKM akan menargetkan sasaran pemuda Desa Mekarwangi, sehingga terpapar dengan pengetahuan tentang Rumah Sehat, sehingga jika mereka sudah berkeluarga, mereka sudah mengetahui prinsip-prinsip dasar dalam desain rumah sehat ketika mereka akan membangun rumah sendiri.

\section{Daftar Pustaka}

Desa Mekarwangi (2013). Rencana Pembangunan Jangka Menengah Desa Mekarwangi 2013 - 2019. Desa Mekarwangi - Kabupaten Tangerang.

Desa Mekarwangi (2015). Buku Monograf Desa Mekarwangi 2015. Desa Mekarwangi - Kabupaten Tangerang.

Khamdevi (2018). Studi Potensi Lokal Kampung Cilegong Desa Mekarwangi dengan Analisis Spirit of Place. Jurnal MArKa Vol.2 No.1.

Khamdevi dan Wibowo (2016). Kajian Pedoman Desain Rumah Desa Mekarwangi - Banten: Dengan Pendekatan Smart Growth dan Sustainable Development. Seminar Nasional Arsitektur Smart City. Universitas Khairun Ternate.

Khamdevi dan Wibowo (2018). Studio Perancangan Arsitektur Kota: Kampung Wisata Hijau Organik Cilegong, Desa Mekarwangi. Wikrama Parahita : Jurnal Pengabdian Masyarakat Vol.1 No.2.

Wibowo dan Khamdevi (2017). Karakteristik Arsitektur Desa Mekarwangi, Cisauk. Jurnal NalArs Vol. 16 No.2. 